\title{
Recent trends in the management of advanced prostate
}

\section{cancer [version 1; peer review: 3 approved]}

\section{Chad Ritch (D1, Michael Cookson²}

${ }^{1}$ Department of Urology, Miller School of Medicine, University of Miami, Miami, FL, USA

${ }^{2}$ Department of Urology, University of Oklahoma College of Medicine and Stephenson Cancer Center, Oklahoma City, OK, USA

V1 First published: 21 Sep 2018, 7(F1000 Faculty Rev):1513

https://doi.org/10.12688/f1000research.15382.1

Latest published: 21 Sep 2018, 7(F1000 Faculty Rev):1513

https://doi.org/10.12688/f1000research.15382.1

\section{Abstract}

Advanced prostate cancer includes a wide spectrum of disease ranging from hormone naïve or hormone sensitive to castration resistant, both containing populations of men who have demonstrable metastatic and non-metastatic states. The mainstay of treatment for metastatic hormone-sensitive prostate cancer is androgen deprivation therapy (ADT). However, recent level 1 evidence demonstrates that the addition of chemotherapy or abiraterone acetate to ADT results in significant survival advantage as compared with ADT alone. Furthermore, in non-metastatic castration-resistant prostate cancer (MO CRPC), two second-generation anti-androgens, apalutamide and enzalutamide, when used in combination with ADT, have demonstrated a significant benefit in metastasis-free survival. Here, we review the most recent studies leading to these significant changes in the treatment of advanced prostate cancer.

\section{Keywords}

prostate cancer, chemohormonal therapy, castration resistant prostate cancer, hormone sensitive metastatic prostate cancer

\section{Open Peer Review}

Approval Status

1 2 3

version 1

21 Sep 2018

Faculty Reviews are review articles written by the prestigious Members of Faculty Opinions. The articles are commissioned and peer reviewed before publication to ensure that the final, published version is comprehensive and accessible. The reviewers who approved the final version are listed with their names and affiliations.

1. Christopher B Anderson, Columbia University Medical Center, New York, USA

2. Alicia K Morgans, Northwestern University Feinberg School of Medicine, Chicago, USA

3. Axel Heidenreich, Universitätsklinikum Köln, Köln, Germany

Any comments on the article can be found at the end of the article. 
Corresponding author: Michael Cookson (michael-cookson@ouhsc.edu)

Author roles: Ritch C: Conceptualization, Data Curation, Formal Analysis, Investigation, Methodology, Supervision, Validation, Writing Original Draft Preparation, Writing - Review \& Editing; Cookson M: Conceptualization, Data Curation, Formal Analysis, Investigation, Methodology, Supervision, Validation, Writing - Original Draft Preparation, Writing - Review \& Editing

Competing interests: Michael S. Cookson is on the advisory board (honorarium) for Bayer and Janssen. Chad R. Ritch declares that he has no competing interests.

Grant information: The author(s) declared that no grants were involved in supporting this work.

Copyright: $\odot 2018$ Ritch C and Cookson M. This is an open access article distributed under the terms of the Creative Commons Attribution License, which permits unrestricted use, distribution, and reproduction in any medium, provided the original work is properly cited.

How to cite this article: Ritch $\mathrm{C}$ and Cookson $\mathrm{M}$. Recent trends in the management of advanced prostate cancer [version 1; peer review: 3 approved] F1000Research 2018, 7(F1000 Faculty Rev):1513 https://doi.org/10.12688/f1000research.15382.1

First published: 21 Sep 2018, 7(F1000 Faculty Rev):1513 https://doi.org/10.12688/f1000research.15382.1 


\section{Introduction}

There have been significant strides in the management of prostate cancer over the past decade. The majority of newly diagnosed cases $(80 \%)$ are localized prostate cancer, and the remaining cases are advanced or metastatic disease ${ }^{1}$. Overall survival (OS) rates in localized disease are very high; however, this decreases dramatically for advanced and metastatic cases and ranges from $26 \%$ to $30 \%$ at 5 years $^{2}$. Unique to prostate cancer is the fact that cancer cells are highly sensitive to the manipulation of the androgen pathway ${ }^{3,4}$. Testosterone and its metabolites have a stimulatory effect on prostate cancer cell growth, and hormonal manipulation and castration can induce prostate cancer cell death ${ }^{5}$. Therefore, the initial management of metastatic prostate cancer is based on androgen deprivation to achieve castrate levels $(<50 \mathrm{ng} / \mathrm{dL}$ ) of circulating testosterone, thereby depriving the cells of their primary fuel for growth.

For decades, androgen deprivation therapy (ADT), via medical or surgical castration, has been the primary treatment of metastatic prostate cancer. However, patients ultimately progress to castration resistance, wherein prostate cancer cells become resistant to ADT and develop mechanisms to proliferate despite castrate levels of testosterone. Patients who progress to castrationresistant prostate cancer (CRPC) progress rapidly and may die within 2 to 4 years $^{6,7}$. However, prior to 2004, there were no US Food and Drug Administration (FDA)-approved therapies for CRPC until several landmark randomized controlled trials (RCTs) (TAX-327 and SWOG 9916) demonstrated that patients with metastatic CRPC (mCRPC) treated with docetaxel chemotherapy achieved a significant survival advantage compared with placebo ${ }^{8,9}$. Recently, two landmark studies (STAMPEDE and CHAARTED) examined the role of combined chemotherapy and ADT (chemohormonal therapy) as compared with ADT alone in hormone-sensitive disease ${ }^{10,11}$. Additionally, the LATITUDE trial and abiraterone arm of the STAMPEDE trial both demonstrated a survival benefit with abiraterone acetate plus prednisone when combined with ADT over ADT alone for hormone-sensitive prostate cancer $^{12,13}$. All of these studies demonstrated a statistically significant benefit in OS and have changed the management paradigm in metastatic prostate cancer. In the castration-resistant setting, since 2010 and almost every year thereafter, several key RCTs have demonstrated survival benefit with new therapies before and after docetaxel-based chemotherapy. The culmination of these studies has led to the FDA approval of six new agents, which have varying mechanisms of action, in the management of metastatic and non-metastatic (M0) CRPC: sipuleucel-T, abiraterone acetate, enzalutamide, cabazitaxel, radium-223, and apalutamide ${ }^{14-21}$. Of particular significance is the recent approval of apalutamide and enzalutamide in the treatment of M0 CRPC, which was based upon two RCTs (SPARTAN and PROSPER) demonstrating significant improvement in metastasis-free survival (MFS) ${ }^{21,22}$. Prior to these trials, there were no approved agents for M0 CRPC.

The purpose of the present review is to provide an overview of the recent trends and advances in the management of metastatic castration-sensitive prostate cancer (CSPC) and M0 CRPC (Table 1). We will review the literature supporting the approval of upfront chemotherapy in metastatic CSPC as well as recent landmark studies supporting newer therapies for M0 CRPC.

\section{Chemotherapy for metastatic castration-sensitive prostate cancer}

Historically, following progression to CRPC, docetaxel chemotherapy was the first-line agent based on results of the TAX-327 and SWOG 9916 trials $^{8,9}$. TAX-327 demonstrated that docetaxel every 3 weeks significantly decreased risk of death-hazard ratio (HR) 0.76 , 95\% confidence interval (CI) 0.62 to 0.94 , $p=0.009-$ compared with mitoxantrone ${ }^{8}$. The median survival was 18.9 versus 16.4 months for docetaxel compared with mitoxantrone. In SWOG 9916, docetaxel plus estramustine was compared with mitoxantrone plus prednisone, and there was a $20 \%$ reduction in the risk of death with a median survival improvement of about 2 months, favoring docetaxel $(p=0.02)^{9}$. Therefore, docetaxel use was limited to the castrationresistant setting. The GETUG-AFU 15 trial was one of the first

Table 1. Summary of recent trials in castration-sensitive prostate cancer and non-metastatic (M0) castration-resistant prostate cancer.

\begin{tabular}{|c|c|c|c|c|c|}
\hline Trial & Year & Agent & Population & Primary endpoint & $\begin{array}{l}\text { Outcome } \\
\text { summary }\end{array}$ \\
\hline CHAARTED & 2015 & Docetaxel & $\begin{array}{l}\text { Castration-sensitive prostate } \\
\text { cancer (CSPC) }\end{array}$ & Overall survival (OS) & $\begin{array}{l}\text { 13.6-month } \\
\text { OS advantage }\end{array}$ \\
\hline STAMPEDE & 2016 & Docetaxel & CSPC & OS & $\begin{array}{l}\text { 15.6-month } \\
\text { OS advantage }\end{array}$ \\
\hline LATITUDE & 2017 & Abiraterone & CSPC & OS & $\begin{array}{l}7 \% \text { 3-year } \\
\text { OS advantage }\end{array}$ \\
\hline STAMPEDE & 2017 & Abiraterone & CSPC & OS & $\begin{array}{l}17 \% \text { 3-year } \\
\text { OS advantage }\end{array}$ \\
\hline SPARTAN & 2018 & Apalutamide & $\begin{array}{l}\text { MO castration-resistant } \\
\text { prostate cancer (MO CRPC) }\end{array}$ & $\begin{array}{l}\text { Metastasis-free } \\
\text { survival (MFS) }\end{array}$ & $\begin{array}{l}\text { 24.3-month } \\
\text { MFS benefit }\end{array}$ \\
\hline PROSPER & 2018 & Enzalutamide & MO CRPC & MFS & $\begin{array}{l}21.9 \text {-month } \\
\text { MFS benefit }\end{array}$ \\
\hline
\end{tabular}


to investigate the use of docetaxel in the hormone-sensitive setting - about half of the study participants were classified as having low-volume disease-and failed to meet the primary endpoint of OS benefit ${ }^{23}$. However, further investigations into the role of chemotherapy in hormone-sensitive prostate cancer were conducted in the STAMPEDE and CHAARTED (ECOG 3805) trials ${ }^{10,11}$. In the CHAARTED trial, Sweeney et al. performed an RCT of docetaxel (six cycles) plus ADT (chemohormonal therapy) compared with ADT alone in 790 men. The trial demonstrated a significantly longer median OS in the chemohormonal arm compared with ADT alone (57.6 versus 44.0 months; HR $0.61,95 \%$ CI 0.47 to $0.81, p<0.001)^{10}$. Of particular importance was the 17-month survival advantage noted in a subset of patients with high-volume disease (that is, visceral metastases or at least four bone lesions with at least one beyond the vertebral bodies and pelvis) ${ }^{10}$. Therefore, the benefit of chemotherapy in the hormone-sensitive state appears more pronounced in men with high-volume disease.

In the STAMPEDE trial, James et al. demonstrated improved survival in men who received docetaxel at the time of long-term ADT initiation ${ }^{11}$. Unique to the STAMPEDE trial is the multiarm, multi-stage design, wherein patients initiating long-term ADT for newly diagnosed metastatic or locally advanced CSPC or high-risk recurrent prostate cancer are randomly assigned to several additional therapies. For men with metastatic disease at the time of random assignment, the docetaxel arm $(n=592)$ demonstrated a survival advantage (HR $0.76,95 \%$ CI 0.62 to 0.92 , $p=0.005)$ with a median survival difference of 15 months (60 months for docetaxel versus 45 months for ADT). The 5-year survival was $50 \%$ in the docetaxel arm compared with $39 \%$ for the ADT-alone $\operatorname{arm}^{11}$.

\section{Abiraterone for metastatic castration-sensitive prostate cancer}

The implications of the STAMPEDE and CHAARTED trials are significant because chemohormonal therapy has now become a widely considered first-line therapy in high-volume metastatic HSPC. However, the recent LATITUDE trial, which examined the role of abiraterone acetate plus prednisone in combination with ADT in the hormone-sensitive metastatic prostate cancer setting, has also demonstrated a survival advantage compared with ADT plus placebo ${ }^{12}$. Fizazi et al. randomly assigned 1,199 patients with metastatic HSPC to abiraterone acetate plus prednisone combined with ADT versus ADT plus placebo and demonstrated a significant benefit in survival in the abiraterone arm (HR $0.62,95 \%$ CI 0.51 to $0.76, p<0.001)^{12}$. Furthermore, there was a significant benefit with abiraterone with respect to time to initiation of chemotherapy as second-line therapy following disease progression, although fewer patients received secondline chemotherapy than expected ${ }^{12}$. James et al. studied the abiraterone arm of the STAMPEDE trial, in which 1,917 men were randomly assigned to abiraterone plus ADT compared with ADT alone ${ }^{13}$. There was a significant 3-year survival advantage for men in the abiraterone arm of $83 \%$ versus $76 \%$ in the ADT-alone group (HR $0.63,95 \%$ CI 0.52 to $0.76, p<0.001)^{13}$. Importantly, owing to the multi-arm, multi-stage trial design, the patient population differed slightly from that of the LATITUDE group in that some men had node-positive only disease as well as node-negative, non-metastatic disease. Both trials demonstrated a survival benefit, and, as a result, abiraterone acetate as well as chemotherapy may also be considered in metastatic CSPC. A recent analysis of data from the STAMPEDE trial compared abiraterone with docetaxel in the castration-sensitive state and found no difference in overall and prostate cancer-specific survival ${ }^{24}$. Therefore, the approval and utilization of these therapies in combination with ADT in the hormone-sensitive state represent a major advance and paradigm shift in the management of metastatic prostate cancer.

\section{Treatment of non-metastatic castration-resistant prostate cancer}

Progression from the hormone-sensitive to the castrationresistant state is defined as a rising prostate-specific antigen (PSA) with $\mathrm{T}$ levels below $50 \mathrm{ng} / \mathrm{mL}$. In the clinical trial setting, the Prostate Cancer Clinical Trials Working Group 3 definition of PSA progression is an at least $25 \%$ increase, and an absolute increase of at least $2 \mathrm{ng} / \mathrm{mL}$ from the nadir PSA, confirmed at least 3 weeks later $^{25}$. Despite progression to castration resistance, a subset of patients may not harbor detectable metastasis by the traditional imaging techniques used in the trials and therefore are categorized as having M0 CRPC. Patients with M0 CRPC are at high risk for progression to metastatic disease. In fact, within 2 years, about $15 \%$ to $33 \%$ can develop metastasis, implying that castration resistance may lead to rapid progression and potentially a high risk of mortality in this population $^{26,27}$. Until 2018, there were no approved agents for first-line treatment of asymptomatic M0 CRPC. Prior to the current year, guideline recommendations supported continued ADT in M0 CRPC, with close surveillance, because the androgen receptor remains functionally active in this disease $s^{2} \mathrm{t}^{28}$. There were no level 1 data showing a significant therapeutic advantage with any particular therapy in M0 CRPC. Therefore, this disease state represented a challenging clinical conundrum because although castration resistance is a harbinger of metastatic disease and mortality, there were no efficacious options for treatment. If the patient or treating physician wished to pursue treatment, the first-generation anti-androgens (flutamide, bicalutamide, and nilutamide) and first-generation androgen synthesis inhibitors (ketoconazole with steroid) were occasionally used with variable and limited efficacy ${ }^{28,29}$.

In 2016, the STRIVE study demonstrated potential therapeutic benefit with enzalutamide in M0 CRPC. Penson et al. randomly assigned 396 men on ADT, with M0 $(n=139)$ or metastatic ( $\mathrm{n}=257$ ) CRPC, to enzalutamide (160 mg/day) or bicalutamide $(50 \mathrm{mg} / \text { day })^{30}$. Enzalutamide reduced the risk of progression or death by $76 \%$ compared with bicalutamide (HR $0.24,95 \%$ CI 0.18 to $0.32, p<0.001)$ and the median progression-free survival was 13.7 months longer for men in the enzalutamide $\mathrm{arm}^{30}$. Although these findings were noteworthy, they were not sufficient to lead to FDA approval in M0 CRPC.

Recently, apalutamide, a novel non-steroidal anti-androgen which acts as an androgen receptor inhibitor, was studied in patients with M0 CRPC ${ }^{21}$. The SPARTAN trial randomly assigned 
1,207 men with M0 CRPC and a PSA doubling time of less than 10 months to apalutamide versus placebo with a primary endpoint of MFS. Smith et al. demonstrated that men in the apalutamide arm experienced a longer time to progression (HR $0.45,95 \%$ CI 0.32 to $0.63, p<0.001)$ and improved median MFS (40.5 months apalutamide versus 16.2 months placebo: HR $0.28,95 \%$ CI 0.23 to $0.35, p<0.001)^{21}$. Based on the findings of this trial, apalutamide became the first FDA-approved agent in M0 CRPC. The PROSPER trial randomly assigned 1,401 men with M0 CRPC, PSA doubling time of less than 10 months, and PSA of more than $2 \mathrm{ng} / \mathrm{mL}$ to enzalutamide versus placebo ${ }^{22}$. As in the SPARTAN trial, the primary endpoint was MFS. Hussain et al. demonstrated that enzalutamide significantly prolonged median MFS (36.6 versus 14.7 months, $p<0.0001$ ) as well as time to first use of new anti-neoplastic therapy (39.6 versus 17.7 months, $p<0.0001)$ and time to PSA progression $(37.2$ versus 3.9 months, $p<0.0001)$ compared with placebo ${ }^{31}$. Enzalutamide was subsequently FDA-approved for use in M0 CRPC. The importance of patient selection cannot be underestimated. Patients in both of these landmark trials of M0 CRPC were selected on the basis of high risk for metastases as indicated by a rapid PSA doubling time. Furthermore, the newer positron emission tomography imaging-based tracers were not used in these studies and it is possible that a subset of these men had metastases that were not detectable by the limits of conventional computed tomography imaging and nuclear bone scan. In patients with a slow doubling time, observation may be an appropriate management strategy.

\section{Emerging treatments}

Poly(adenosine diphosphate-ribose) polymerase (PARP) is involved in DNA repair, and recent studies have demonstrated an $11.8 \%$ incidence of germline mutations in DNA repair genes in metastatic prostate cancer ${ }^{32}$. PARP inhibition has demonstrated anti-tumor activity in cancer $^{33}$. In a phase 2 trial (TOPARP), the PARP inhibitor olaparib demonstrated good responses in patients with mCRPC $^{34}$. Of 49 evaluable patients who had prior systemic therapy for CRPC, 16 (33\%) responded to therapy with olaparib and $14(88 \%)$ out of 16 responders had mutations in DNA repair genes. PARP inhibitors therefore may play a significant future therapeutic role in a subset of men with DNA repair defects ${ }^{34}$. A recent phase 2 study in mCRPC demonstrated that the combination of olaparib and abiraterone had improved radiographic progression-free survival compared with abiraterone plus placebo (13.8 versus 8.2 months, $p=0.034)^{35}$. Cytotoxic $\mathrm{T}$ lymphocyte-associated antigen-4 (CTLA-4) is a co-inhibitory receptor expressed on $\mathrm{T}$ cells and blocks $\mathrm{T}$-cell activation by binding to co-stimulatory molecules ${ }^{36}$. Ipilimumab is a monoclonal antibody that blocks CTLA-4 and therefore enhances anti-tumor activity by T-cell activation ${ }^{36}$. Kwon et al. conducted a phase 3 RCT of ipilimumab versus placebo in 799 men with mCRPC and demonstrated a non-significant difference in OS of 10 months for placebo and 11.2 for the ipilimumab arm (HR 0.85 , $95 \%$ CI 0.72 to $1.00, p=0.053)^{37}$. The only notable OS benefit was limited to a subset of patients with good prognostic features (alkaline phosphatase concentration of less than 1.5 times upper normal limit, no anemia, and no visceral metastases $)^{37}$.

\section{Conclusions}

There have been significant recent strides in the management of advanced prostate cancer. Major changes in the treatment of hormone-sensitive disease have occurred on the basis of level 1 evidence to support upfront use of docetaxel plus ADT and in addition the use of androgen annihilation with abiraterone acetate plus prednisone in combination with ADT. Also, in the M0 CRPC state, there are now two randomized trials demonstrating improved MFS with the addition of apalutamide or enzalutamide in combination with ADT for patients at high risk for metastases. PARP inhibitors and immunotherapeutic agents such as CTLA-4 inhibitors are also being studied and may become a part of the treatment armamentarium in the near future.

\section{Grant information}

The author(s) declared that no grants were involved in supporting this work.
1. Li J, Siegel DA, King JB: Stage-specific incidence rates and trends of prostate cancer by age, race, and ethnicity, United States, 2004-2014. Ann Epidemiol. 2018; 28(5): 328-30.

PubMed Abstract | Publisher Full Text | Free Full Text

2. Steele CB, Li J, Huang B, et al:: Prostate cancer survival in the United States by race and stage (2001-2009): Findings from the CONCORD-2 study. Cancer. 2017; 123 Suppl 24: 5160-77.

PubMed Abstract | Publisher Full Text | Free Full Text

3. Marques RB, Dits NF, Erkens-Schulze S, et al:: Bypass mechanisms of the androgen receptor pathway in therapy-resistant prostate cancer cell models. PLOS One. 2010; 5(10): e13500.

PubMed Abstract | Publisher Full Text | Free Full Text

4. Harris WP, Mostaghel EA, Nelson PS, et al:: Androgen deprivation therapy: progress in understanding mechanisms of resistance and optimizing androgen depletion. Nat Clin Pract Urol. 2009; 6(2): 76-85. PubMed Abstract | Publisher Full Text | Free Full Text

5. Huggins C, Hodges CV: Studies on prostatic cancer. I. The effect of castration, of estrogen and androgen injection on serum phosphatases in metastatic carcinoma of the prostate. CA Cancer J Clin. 1972; 22(4): 232-40. PubMed Abstract | Publisher Full Text

6. Patrikidou A, Loriot $\mathrm{Y}$, Eymard JC, et al.: Who dies from prostate cancer? Prostate Cancer Prostatic Dis. 2014; 17(4): 348-52. PubMed Abstract | Publisher Full Text

7. Omlin A, Pezaro C, Mukherji D, et al.: Improved survival in a cohort of trial participants with metastatic castration-resistant prostate cancer demonstrates the need for updated prognostic nomograms. Eur Urol. 2013; 64(2): 300-6. PubMed Abstract | Publisher Full Text

8. F Tannock IF, de Wit R, Berry WR, et al.: Docetaxel plus prednisone or mitoxantrone plus prednisone for advanced prostate cancer. $N$ Engl J Med. 2004; 351(15): 1502-12.

PubMed Abstract | Publisher Full Text | F1000 Recommendation

9. F Petrylak DP, Tangen CM, Hussain MH, et al:: Docetaxel and estramustine compared with mitoxantrone and prednisone for advanced refractory prostate cancer. N Engl J Med. 2004; 351(15): 1513-20. PubMed Abstract | Publisher Full Text | F1000 Recommendation 
10. F Sweeney CJ, Chen YH, Carducci M, et al:: Chemohormonal Therapy in Metastatic Hormone-Sensitive Prostate Cancer. N Engl J Med. 2015; 373(8): 737-46.

PubMed Abstract | Publisher Full Text | Free Full Text | F1000 Recommendation

11. F James ND, Sydes MR, Clarke NW, et al:: Addition of docetaxel, zoledronic acid, or both to first-line long-term hormone therapy in prostate cancer (STAMPEDE): survival results from an adaptive, multiarm, multistage, platform randomised controlled trial. Lancet. 2016; 387(10024): 1163-77. PubMed Abstract | Publisher Full Text | Free Full Text | F1000 Recommendation

12. F Fizazi K, Tran N, Fein L, et al:: Abiraterone plus Prednisone in Metastatic Castration-Sensitive Prostate Cancer. N Engl J Med. 2017; 377(4): 352-60. PubMed Abstract | Publisher Full Text | F1000 Recommendation

13. F James ND, de Bono JS, Spears MR, et al: Abiraterone for Prostate Cancer Not Previously Treated with Hormone Therapy. N Engl J Med. 2017; 377(4) 338-51

PubMed Abstract | Publisher Full Text | Free Full Text | F1000 Recommendation

14. F Kantoff PW, Higano CS, Shore ND, et al: Sipuleucel-T immunotherapy for castration-resistant prostate cancer. N Engl J Med. 2010; 363(5): 411-22. PubMed Abstract | Publisher Full Text | F1000 Recommendation

15. F de Bono JS, Logothetis CJ, Molina A, et al.: Abiraterone and increased survival in metastatic prostate cancer. N Engl J Med. 2011; 364(21): 1995-2005. PubMed Abstract | Publisher Full Text | Free Full Text | F1000 Recommendation

16. Ryan CJ, Smith MR, Fizazi K, et al:: Abiraterone acetate plus prednisone versus placebo plus prednisone in chemotherapy-naive men with metastatic castration-resistant prostate cancer (COU-AA-302): final overall survival analysis of a randomised, double-blind, placebo-controlled phase 3 study. Lancet Oncol. 2015; 16(2): 152-60. PubMed Abstract | Publisher Full Text

17. F Scher HI, Fizazi K, Saad F, et al.: Increased survival with enzalutamide in prostate cancer after chemotherapy. N Engl J Med. 2012; 367(13): 1187-97. PubMed Abstract | Publisher Full Text | F1000 Recommendation

18. F Beer TM, Armstrong AJ, Rathkopf DE, et al.: Enzalutamide in metastatic prostate cancer before chemotherapy. N Engl J Med. 2014; 371(5): 424-33. PubMed Abstract | Publisher Full Text | Free Full Text | F1000 Recommendation

19. F de Bono JS, Oudard S, Ozguroglu M, et al:: Prednisone plus cabazitaxel or mitoxantrone for metastatic castration-resistant prostate cancer progressing after docetaxel treatment: a randomised open-label trial. Lancet. 2010; 376(9747): 1147-54.

PubMed Abstract | Publisher Full Text | F1000 Recommendation

20. F Parker C, Nilsson S, Heinrich D, et al:: Alpha emitter radium-223 and survival in metastatic prostate cancer. N Engl J Med. 2013; 369(3): 213-23. PubMed Abstract | Publisher Full Text | F1000 Recommendation

21. F Smith MR, Saad F, Chowdhury S, et al: Apalutamide Treatment and Metastasis-free Survival in Prostate Cancer. N Engl J Med. 2018; 378(15): 1408-18.

PubMed Abstract | Publisher Full Text | F1000 Recommendation

22. Hussain M, Fizazi K, Saad F, et al: PROSPER: A phase 3, randomized, doubleblind, placebo (PBO)-controlled study of enzalutamide (ENZA) in men with nonmetastatic castration-resistant prostate cancer (M0 CRPC). J Clin Oncol. 2018; 36(6_suppl): 3 . Publisher Full Text

23. Gravis G, Fizazi K, Joly F, et al: Androgen-deprivation therapy alone or with docetaxel in non-castrate metastatic prostate cancer (GETUG-AFU 15): a randomised, open-label, phase 3 trial. Lancet Oncol. 2013; 14(2): 149-58. PubMed Abstract | Publisher Full Text
24. Sydes MR, Spears MR, Mason MD, et al:: Adding abiraterone or docetaxel to long-term hormone therapy for prostate cancer: directly randomised data from the STAMPEDE multi-arm, multi-stage platform protocol. Ann Oncol. 2018; 29(5): 1235-48.

PubMed Abstract | Publisher Full Text | Free Full Text

25. Scher HI, Morris MJ, Stadler WM, et al.: Trial Design and Objectives for Castration-Resistant Prostate Cancer: Updated Recommendations From the Prostate Cancer Clinical Trials Working Group 3. J Clin Oncol. 2016; 34(12): 1402-18.

PubMed Abstract | Publisher Full Text | Free Full Text

26. Hirst CJ, Cabrera C, Kirby M: Epidemiology of castration resistant prostate cancer: a longitudinal analysis using a UK primary care database. Cancer Epidemiol. 2012; 36(6): e349-53.

PubMed Abstract | Publisher Full Text

27. Smith MR, Kabbinavar F, Saad F, et al.: Natural history of rising serum prostatespecific antigen in men with castrate nonmetastatic prostate cancer. $J$ Clin Oncol. 2005; 23(13): 2918-25.

PubMed Abstract | Publisher Full Text

28. Cookson MS, Lowrance WT, Murad MH, et al.: Castration-resistant prostate cancer: AUA guideline amendment. J Urol. 2015; 193(2): 491-9. PubMed Abstract | Publisher Full Text

29. Cookson MS, Roth BJ, Dahm P, et al:: Castration-resistant prostate cancer: AUA Guideline. J Urol. 2013; 190(2): 429-38. PubMed Abstract | Publisher Full Text

30. Penson DF, Armstrong AJ, Concepcion R, et al: Enzalutamide Versus Bicalutamide in Castration-Resistant Prostate Cancer: The STRIVE Trial. $J$ Clin Oncol. 2016; 34(18): 2098-106. PubMed Abstract | Publisher Full Tex

31. F Hussain M, Fizazi K, Saad F, et al.: Enzalutamide in Men with Nonmetastatic, Castration-Resistant Prostate Cancer. N Engl J Med. 2018; 378(26): 2465-74

PubMed Abstract | Publisher Full Text | F1000 Recommendation

32. F Pritchard CC, Mateo J, Walsh MF, et al:: Inherited DNA-Repair Gene Mutations in Men with Metastatic Prostate Cancer. N Engl J Med. 2016; 375(5): 443-53.

PubMed Abstract | Publisher Full Text | Free Full Text | F1000 Recommendation

33. F Fong PC, Boss DS, Yap TA, et al:: Inhibition of poly(ADP-ribose) polymerase in tumors from BRCA mutation carriers. N Engl J Med. 2009; 361(2): 123-34.

PubMed Abstract | Publisher Full Text | F1000 Recommendation

34. F Mateo J, Carreira S, Sandhu S, et al:: DNA-Repair Defects and Olaparib in Metastatic Prostate Cancer. N Engl J Med. 2015; 373(18): 1697-708. PubMed Abstract | Publisher Full Text | Free Full Text | F1000 Recommendation

35. Clarke N, Wiechno P, Alekseev B, et al:: Olaparib combined with abiraterone in patients with metastatic castration-resistant prostate cancer: a randomised, double-blind, placebo-controlled, phase 2 trial. Lancet Oncol. 2018; 19(7): 975-86.

PubMed Abstract | Publisher Full Text

36. Carosella ED, Ploussard G, LeMaoult J, et al:: A Systematic Review of Immunotherapy in Urologic Cancer: Evolving Roles for Targeting of CTLA-4, PD-1/PD-L1, and HLA-G. Eur Urol. 2015; 68(2): 267-79. PubMed Abstract | Publisher Full Text

37. $\mathrm{F}$ Kwon $\mathrm{ED}$, Drake $\mathrm{CG}$, Scher $\mathrm{HI}$, et al: Ipilimumab versus placebo after radiotherapy in patients with metastatic castration-resistant prostate cancer that had progressed after docetaxel chemotherapy (CA184-043): a multicentre, randomised, double-blind, phase 3 trial. Lancet Oncol. 2014; 15(7): 700-12. PubMed Abstract | Publisher Full Text | Free Full Text | F1000 Recommendation 


\section{Open Peer Review}

\section{Current Peer Review Status:}

\section{Editorial Note on the Review Process}

Faculty Reviews are review articles written by the prestigious Members of Faculty Opinions. The articles are commissioned and peer reviewed before publication to ensure that the final, published version is comprehensive and accessible. The reviewers who approved the final version are listed with their names and affiliations.

\section{The reviewers who approved this article are:}

\section{Version 1}

\section{Axel Heidenreich}

Klinik für Urologie, Uro-Onkologie, Roboter-assistierte und Spezielle Urologische Chirurgie, Universitätsklinikum Köln, Köln, Germany

Competing Interests: No competing interests were disclosed.

\section{Alicia K Morgans}

Division of Hematology/Oncology and Robert H. Lurie Comprehensive Cancer Center, Northwestern University Feinberg School of Medicine, Chicago, IL, USA

Competing Interests: Consulting honoraria from Janssen, Sanofi, Bayer, Genentech, and Astra Zeneca.

\section{Christopher B Anderson}

Department of Urology, Herbert Irving Cancer Center, Columbia University Medical Center, New York, New York, USA

Competing Interests: No competing interests were disclosed.

The benefits of publishing with F1000Research:

- Your article is published within days, with no editorial bias

- You can publish traditional articles, null/negative results, case reports, data notes and more

- The peer review process is transparent and collaborative

- Your article is indexed in PubMed after passing peer review

- Dedicated customer support at every stage

For pre-submission enquiries, contact research@f1000.com 